Archives of Agriculture and Environmental Science

\title{
Response surface methodology based optimization of cadmium and lead remediation from aqueous solution by water hyacinth (Eichhornia crassipes [Mart.] Solms) and its anatomical study
}

\section{Vinod Kumar* (D) , Jogendra Singh and Pankaj Kumar}

Agro-ecology and Pollution Research Laboratory, Department of Zoology and Environmental Science, Gurukula Kangri Vishwavidyalyaya, Haridwar- 249404, Uttarakhand, INDIA

"Corresponding author's E-mail: drvksorwal@gkv.ac.in

\section{ARTICLE HISTORY}

Received: 11 April 2018

Revised received: 23 May 2018

Accepted: 28 May 2018

Keywords

E. crassipes

Heavy metal toxicity

Phytoremediation

Reduction efficiency

RSM

Stomata damage

\section{ABSTRACT}

This experiment was performed to optimize the response surface methodology (RSM) based reduction of cadmium $\left(\mathrm{Cd}^{2+}\right)$ and lead $\left(\mathrm{Pb}^{2+}\right)$ from the aqueous solution and to study anatomical effects of $\mathrm{Cd}^{2+}$ and $\mathrm{Pb}^{2+}$ stress on stomata of water hyacinth (Eichhornia crassipes [Mart.] Solms) during phytoremediation. Laboratory experiments were carried out to grow E. crassipes plants in six treatments of $\mathrm{Cd}^{2+}$ and $\mathrm{Pb}^{2+}$ viz., $0 \mathrm{mgL}^{-1}$ (Control), $2 \mathrm{mgL}^{-1}, 4 \mathrm{mgL}^{-1}, 6 \mathrm{mgL}^{-1}, 8 \mathrm{mgL}^{-1}$ and $10 \mathrm{mgL}^{-1}$ in 25 liter capacity glass aquariums. A 2-factor central composite design (CCD) with total 25 experimental runs and the predictor regression model equation was applied to optimize the prime conditions for the $\mathrm{Cd}^{2+}$ and $\mathrm{Pb}^{2+}$ reduction. Different plant growth attributes viz., translocation factor; kinetic plant growth rate, fresh plant biomass and total chlorophyll content were also found highest up to $4 \mathrm{mgL}^{-1}$ concentration of $\mathrm{Cd}^{2+}$ and $\mathrm{Pb}^{2+}$. Structural damage in the stomata of E. crassipes was evaluated under microscopic view and found that above $4 \mathrm{mgL}^{-1}$ concentration of $\mathrm{Cd}^{2+}$ and $\mathrm{Pb}^{2+}$ in the medium, significant structural damage to the stomata of leaves of the $E$. crassipes occurred. The results of this study concluded that $E$. crassipes can remediate $\mathrm{Cd}^{2+}$ and $\mathrm{Pb}^{2+}$ from the medium more efficiently at $1.22 \mathrm{mgL}^{-1}$ concentration and the developed model can be used to navigate the design space. Furthermore, the different plant growth attributes were also affected above $4 \mathrm{mgL}^{-1}$ concentration of $\mathrm{Cd}^{2+}$ and $\mathrm{Pb}^{2+}$ in the medium.

(C)2018 Agriculture and Environmental Science Academy

Citation of this article: Kumar, V., Singh, J. and Kumar, P. (2018). Response surface methodology based optimization of cadmium and lead remediation from aqueous solution by water hyacinth (Eichhornia crassipes [Mart.] Solms) and its anatomical study. Archives of Agriculture and Environmental Science, 3(2): 163-173, https://dx.doi.org/10.26832/24566632.2018.0302010

\section{INTRODUCTION}

Environmental pollution caused by heavy metals has become a global issue, which extremely affects growth and development of agricultural crops, aquatic plants as well as the native flora. The devastating impacts of heavy metals are reduction in growth and development, photosynthetic rate, chloroplast, photosynthetic pigments and more importantly disturbed plant water relation. Heavy metals in soil and water can also induce the alteration in anatomical parameters of plants (Batool et al., 2015). However, tolerance to these toxic metals is attained and varies among diverse species, and even within populations of a same plant species. Additionally, the study of the effects of toxicants including heavy metals on the growth and development of plants represents not only a theoretically but also practically relevant problem with respect to increasing industrialization (Sayed, 1997; Freitas et al., 2007).

The aquatic macrophytes are believed to eliminate heavy metals from aquatic bodies through bio-accumulation process, where the high amounts of the heavy metals are captured in their body parts and it is likely to be useful for the reduction of the pollutants along with heavy metals from the industrial effluents by an environmental friendly approach (Wei et al., 2014). Hyperaccumulator plants are able to remove and store significant 
amount of toxic and metallic contaminant (Letachowicz et al., 2006; Kumar and Chopra 2016; Di et al., 2015; Zaranyika and Nyati, 2017). These plants can be transplanted to sites for bio-filtering heavy metals from wastewater. Higher the affinity of the metal for the sorbate plant species, the latter is attraction and is bounded with different mechanisms. The process of bioremediation continues until an equilibrium is established between the amount of toxicant sorbate species and its portion remaining in the solution (Mahmood et al., 2010). Earlier studies of aquatic plants also stated that toxicant acts as an on/off switch for stomata (Baruah et al., 2012; lida et al., 2016). Hyperaccumulating aquatic plants like water hyacinth (Eichhornia crassipes), water caltrop (Trapa natans) and water lettuce (Pistia stratiotes) which are capable to remove heavy metals from contaminated water bodies commonly known as phytoremediation of heavy metals from wastewaters (Liao and Chang, 2004; Deka and Sarma, 2011; Kumar et al., 2017a; Kumar et al., 2018). Heavy metals are actively captured by plant roots and then transferred to upper sections of the plants viz., stem, leaves and fruits (Perfus-Barbeoch et al., 2002). Heavy metals such as copper $(\mathrm{Cu})$, zinc $(\mathrm{Zn})$, cobalt (Co), and iron (Fe) are essential in trace amounts in catalyzation of metabolic activities in plants. However, excess of any kind of metal adversely affects plant metabolism and growth rate (Hall, 2002; Chandra and Kang, 2016). Stomata aperture is strongly regulated by divergent exogenous stimuli, such as light, drought stress, pathogens, temperature and others (Acharya and Assmann, 2009). Rapid stomata closure in leaves occurs in response to water deficiency and optimizes water use efficiency, thereby playing crucial roles in drought stress tolerance. Like this, stomata closing may also be affected by a direct interaction of the toxic metal at the guard cell level. Alternatively, increased stomata resistance may also be a consequence of toxic effects in other plant tissues, leading to decreased water accessibility in leaves and finally the stomata regulation (Cai et al., 2017). These characteristics may be used as heavy metal sensitivity markers in aquatic plants. The aquatic plants are well adapted to grow in a wide range of environmental features including $\mathrm{pH}$, electrical conductivity and temperature. Plants being used for the phytoremediation must be capable to tolerate the multiple forms and concentrations of the contaminants present in their environment (Kumar and Chopra, 2016; Kumar et al., 2017a, c). Furthermore, the phytoremediation efficiency is depended upon leaf structure (Hessini et al., 2008) because the leaf traits are often linked to the resource use efficiency of plants (Singh et al., 2012).

Response surface methodology (RSM) is a set of mathematical and statistical methods applied for designing, refining, validating and optimizing procedures and experiments (Anderson and Whitcomb, 2005). This technique is used for evaluating the impacts of discrete factor, their comparative significance and the dependency of two or more variables and finding the best conditions for preferred responses or results of an experiment (Wantala et al., 2012). RSM is used to find the optimum operating conditions for the system and to estimate a region that fulfils the operating conditions (Mourabet et al., 2012).
A number of studies have been reported on the toxic effect of different heavy metals on the structure of stomata in various aquatic macrophytes which are being used for phytoremediation purposes. But, the present investigation was a novel study for optimizing response surface methodology (RSM) based reduction of $\mathrm{Cd}^{2+}$ and $\mathrm{Pb}^{2+}$ from the aqueous solution along with to study anatomical effects of $\mathrm{Cd}^{2+}$ and $\mathrm{Pb}^{2+}$ toxicity on stomata of water hyacinth (Eichhornia crassipes [Mart.] Solms) during phytoremediation.

\section{MATERIALS AND METHODS}

Test plant species (E. crassipes) for phytoremediation experiments

E. crassipes is a free floating aquatic plant and belongs to the family Pontederiaceae, was used to as test plant for this experiment. E. crassipes is a rapid growing aquatic macrophyte and its name Eichhornia was derived from the famous $19^{\text {th }}$ century Prussian politician J.A.F. Eichhorn. E. crassipes is an aquatic plant having good feasibility of phytoremediation of wastewaters containing metallic and other kind of chemical pollutants (Kumar et al., 2017a, b). For this experiment, juvenile plants of $E$. crassipes were collected from the adjacent ponds situated at

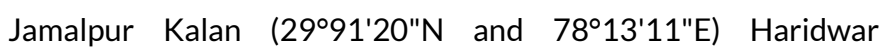
(Uttarakhand), India. The healthy and disease free plants of $E$. crassipes were accurately weighted before and then used for the phytoremediation experiment.

Preparation of $\mathrm{Cd}^{2+}$ and $\mathrm{Pb}^{2+}$ stock solutions

The stock solutions of cadmium $\left(\mathrm{Cd}^{2+}\right)$ and lead $\left(\mathrm{Pb}^{2+}\right)$ of 100 $\mathrm{mgL}^{-1}$ concentration were prepared by dissolving solid $\mathrm{CdSO}_{4}$. $2 \mathrm{H}_{2} \mathrm{O}$ (pure analytical grade, Sigma Aldrich Inc.) and solid $\mathrm{PbSO}_{4}$ (pure analytical grade, Sigma Aldrich Inc.), respectively, into appropriate amount of heavy metal free bore well water (BWW). Further, the stock solutions were diluted to obtain 2 $\mathrm{mgL}^{-1}, 4 \mathrm{mgL}^{-1}, 6 \mathrm{mgL}^{-1}, 8 \mathrm{mgL}^{-1}$ and $10 \mathrm{mgL}^{-1}$ concentrations. The stock solutions were standardized accordingly to make sure that the correct concentration was achieved.

\section{Design of phytoremediation experiment}

The phytoremediation experiment using E. crassipes was conducted in the Multipurpose Experimental Area (MEA) located at Department of Zoology and Environmental Science, Gurukula Kangri Vishwavidyalyaya, Haridwar (Uttarakhand), India (29 $55^{\prime} 13^{\prime \prime} \mathrm{N}$ and $\left.78^{\circ} 7^{\prime} 23^{\prime \prime} \mathrm{E}\right)$. Glass aquariums of 25 liter capacity were used as phytoremediation vessel. Three replicates of each concentrations of $\mathrm{Cd}^{2+}$ and $\mathrm{Pb}^{2+}$ viz., $0 \mathrm{mgL}^{-1}$ or control (BWW), 2 $\mathrm{mgL}^{-1}\left(\mathrm{~T}_{1}\right), 4 \mathrm{mgL}^{-1}\left(\mathrm{~T}_{2}\right), 6 \mathrm{mgL}^{-1}\left(\mathrm{~T}_{3}\right), 8 \mathrm{mgL}^{-1}\left(\mathrm{~T}_{4}\right)$ and $10 \mathrm{mgL}^{-1}\left(\mathrm{~T}_{5}\right)$ were made accordingly and used as growing medium of $E$. crassipes. Bore well water (BWW) was used as control/blank ( 0 mgL' $\left.{ }^{1}\right)$ which was analyzed for heavy metals before the experiment, and found free of $\mathrm{Cd}^{2+}$ and $\mathrm{Pb}^{2+}$ (Kumar et al., 2017b). For this experiment the glass aquariums were filled with 20 liter volume of growing medium and set in an order as shown in the Figure 1 and three replicates of each treatment were implemented. 
Heavy metals characterization of growing medium

The growing medium was characterized for two heavy metals viz., $\mathrm{Cd}^{2+}$ and $\mathrm{Pb}^{2+}$. The concentration of $\mathrm{Cd}^{2+}$ and $\mathrm{Pb}^{2+}$ were analyzed before, during and after the phytoremediation experiments. The analysis of $\mathrm{Cd}^{2+}$ and $\mathrm{Pb}^{2+}$ was performed at every 15 days interval (Initial day, $15^{\text {th }}$ day, $30^{\text {th }}$ day, $45^{\text {th }}$ day and $60^{\text {th }}$ day) by following the standard methods and procedures prescribed by the AOAC (2005); APHA (2012) and Chaturvedi and Sankar (2006). $\mathrm{Cd}^{2+}$ and $\mathrm{Pb}^{2+}$ were analyzed by using an Atomic Absorption Spectroscopy (Model- PerkinElmer, Analyst 800, GenTech Scientific Inc., Arcade, NY).

Determination of growth attributes of $E$. crassipes plants

Total fresh biomass, total chlorophyll content and kinetic plant growth rate of E. crassipes plants were determined before and during the phytoremediation experiments at intervals of 0,15 , 30,45 and 60 days in each of treatment. Fresh weight of $E$. crassipes plants was determined by using a digital balance. Total chlorophyll content (chlorophyll a and b) of E. crassipes was analyzed using acetone (80\%) extraction method and the single beam absorbance was recorded with help of a UV-Vis spectrophotometer (Agilent, 60 Cary UV-Vis) (Aron, 1949; Kumar et al., $2017 a, b)$. The quantity of chlorophyll a, chlorophyll b and total chlorophyll of E. crassipes were calculated using the equation 1 , 2 and 3.

Total chlorophyll content: $20.2(\mathrm{~A} 645)+8.02(\mathrm{~A} 663)$

Chlorophyll a: 12.7(A663) - 2.69(A645)

Chlorophyll b: 22.9(A645) - 4.68(A663)

Where, $A 645$ and $A 663$ are the absorbance taken at 645 and $663 \mathrm{~nm}$, respectively.

The kinetic plant growth rate of $E$. crassipes plants was determined by comparing the final weight with the initial weight. The equation 4 was used to calculate the kinetic plant growth rate (Hunt 1978; Kumar et al., 2017a, b).

$$
\text { Kinetic growth rate }=\frac{\mathrm{InW}_{2}-\mathrm{InW}_{1}}{\left(\mathrm{t}_{2}-\mathrm{t}_{1}\right)}
$$

Where, $\ln W_{2}$ and $\ln W_{1}$ are initial and final fresh biomass of plants at harvest, respectively, and $\left(t_{2}-t_{1}\right)$ is the time of the experiment in days. The results were represented as increase of biomass per unit mass per day $\left(\mathrm{gg}^{-1} \mathrm{~d}^{-1}\right)$.

Translocation factor of $\mathrm{Cd}^{2+}$ and $\mathrm{Pb}^{2+}$ in roots and leaves of $\mathrm{E}$. crassipes

Translocation factor $\left(T_{f}\right)$ is important attribute for screening hyper accumulator's plants suitable for phytoextraction of heavy metals. Metals that are accumulated by plants and largely stored in the roots of the plants are indicated by $T_{f}$ values. Greater the $T_{f}$ value more is the $s$ translocation of heavy metal in the aerial parts of the plant (Mellem et al., 2009). This is the ratio which represents the ability of a plant to translocate metals from its roots to its aerial parts (Mellem et al., 2012). $T_{f}$ of E. crassipes for $\mathrm{Cd}^{2+}$ and $\mathrm{Pb}^{2+}$ was calculated using the equation 5 .

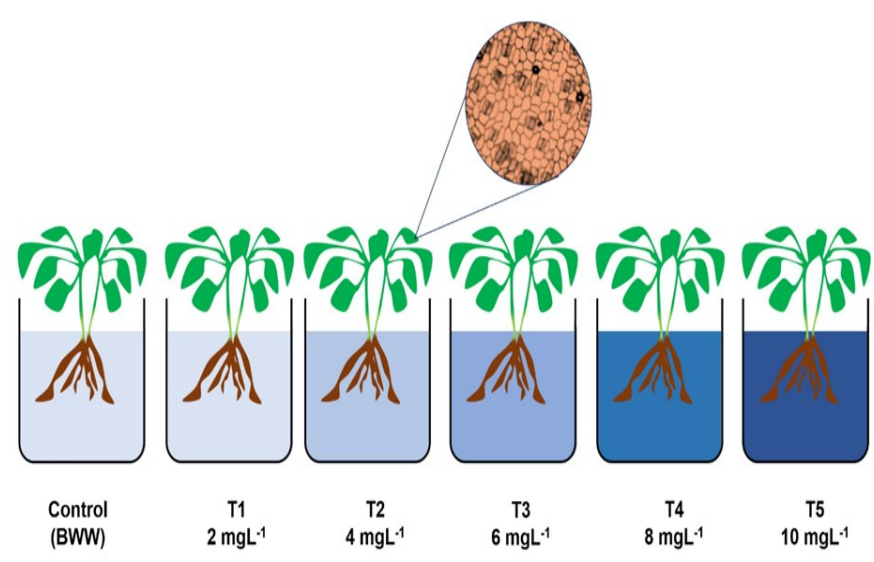

Figure 1. Experimental setup for phytoremediation using E. crassipes.

$$
\text { Translocation factor }\left(T_{\mathrm{f}}\right)=\frac{c_{a}}{c_{r}}
$$

Where, $C_{a}$ and $C_{r}$ are the concentration of metal in aerial parts and roots of $E$. crassipes, respectively.

Optimization of $\mathrm{Cd}^{2+}$ and $\mathrm{Pb}^{2+}$ reduction using response surface methodology

The reduction of $\mathrm{Cd}^{2+}$ and $\mathrm{Pb}^{2+}$ from the growing medium was optimized by response surface methodology (RSM). There are three steps, essentially used to optimize any RSM model viz., statistical designing the experiment, determining the coefficient values of mathematical model and performing response prediction and validity of the model (Mondal et al., 2013). A 2-factor Central-Composite Design (CCD) was applied to evaluate the effect of the selected parameters on the reduction of $\mathrm{Cd}^{2+}$ and $\mathrm{Pb}^{2+}$ from aqueous solutions by $E$. crassipes. A total 25 experimental runs were designed (Table 1 ) and performed to evaluate the reduction of $\mathrm{Cd}^{2+}$ and $\mathrm{Pb}^{2+}$ separately. Two factors viz., $\mathrm{X}_{1}$ : $\mathrm{Cd}^{2+}$ and $\mathrm{Pb}^{2+}$ treatment concentration (2, 4, 6, 8 and $10 \mathrm{mgL}^{-1}$ ) and $X_{2}$ : Experimental times (0, 15, 30, 45 and 60 day) were selected as the independent variables. While, $Y_{1}$ and $Y_{2}$ for percent (\%) reduction of $\mathrm{Cd}^{2+}$ and $\mathrm{Pb}^{2+}$ from the growing medium were taken as dependent variables to study the response of independent variables, respectively.

The selected variables were coded according to the equation 6 given below.

$$
x_{i}=\frac{x_{i}-x_{0}}{\Delta x_{i}}
$$

Where, $x_{i}$ is the coded value of an independent variable, $X_{i}$ is the real value of an independent variable, $X_{0}$ is the real value of an independent variable at the center point and $\Delta \mathrm{X}_{\mathrm{i}}$ is the step change value.

The percent reduction $\left(\mathrm{Y}_{\mathrm{i}}\right)$ of $\mathrm{Cd}^{2+}$ and $\mathrm{Pb}^{2+}$ was calculated according to the equation 7 (Zheng and Wang, 2010).

$$
Y(\%)=\frac{c_{0}-c_{t}}{c_{0}} \times 100
$$

Where, $Y$ is the reduction efficiency (\%), and $C_{0}$ and $C_{t}$ are the initial and residual (after $t$ days) concentrations of $\mathrm{Cd}^{2+}$ and $\mathrm{Pb}^{2+}$ in the aqueous solution $\left(\mathrm{mgL}^{-1}\right)$. The experimental results were 
analyzed using Design Expert Version 11.0 (Stat Ease) software package and polynomial regression model was used as per equation 8 (Salehi et al., 2017).

$$
Y(\%)=\beta_{0}+\sum \beta_{i} X_{i}+\sum \beta_{i i} X_{i}^{2}+\sum \beta_{i j} X_{i} X_{j}
$$

Where, $Y$ is the response; $X_{i}$ and $X_{j}$ are the independent variables; $\beta_{0}$ is an established coefficient and $\beta_{i} \beta_{i, j}$ and $\beta$ ii are the regression coefficients, respectively.

\section{Preparation of slides and microscopic analysis}

Fresh leaves of E. crassipes were used to prepare slides for microscopic observations. Fresh leaf samples from each aquarium were collected at intervals of every 15 days (Initial day, $15^{\text {th }}$ day, $30^{\text {th }}$ day, $45^{\text {th }}$ day and $60^{\text {th }}$ day) at $12: 00 \mathrm{pm}$ noon (IST/ +5 :30GTM). Sharp and new blades were used to dissect the leaves carefully, while the sections were cut with a dissecting scope by placing blade on its axis i.e. perpendicular to the angle of view. The prepared slides were stained with Safranine-O reagent solution (10\%) according to standard method described by Hultine and Marshall (2001). For assessing the relative changes in stomata structure and density, plant leaf peel was expanded on the slides, dried and rewetted. Images were captured with help of a compound microscope fitted with digital camera (Model- Olympus, CH2Oi). Stomata counting were performed under the microscope at resolution of $40 \mathrm{X}$ i.e. number of total stomata in per view (50) and the number of damaged stomata. Stomata were counted in four microscopic views in each slide and the calculated mean value was used as average stomata damage count. The degree of stomata damage was calculated with the equation 9 given below:

$$
\% \text { Stomata Damage }\left(\mathrm{S}_{\mathrm{D}}\right)=\frac{(\mathrm{DS} \times 100)}{(\mathrm{TS})}
$$

Where, DS is the number of damaged stomata and TS is the total number of stomata per view.

\section{Statistical analysis}

The results of the present study were the mean of three replicates. The experimental results were analyzed with Design Expert Version 11.0 (Stat Ease). A single way Analysis of Variance (ANOVA) test was applied to the obtained data with the help of MS Excel 2013 and the graphs were plotted with the help of OriginLab Pro Version 9 software.

\section{RESULTS AND DISCUSSION}

Effect of $\mathrm{Cd}^{2+}$ and $\mathrm{Pb}^{2+}$ treatment on growth attributes of $\mathrm{E}$. crassipes

The results showed that after 60 days of phytoremediation experiment the total fresh biomass of $E$. crassipes plants increased up to $4 \mathrm{mgL}^{-1}$ and then started decreasing above this concentration of $\mathrm{Cd}^{2+}$ and $\mathrm{Pb}^{2+}$. Figure 2 represents the total fresh biomass in $\mathrm{Cd}^{2+}$ and $\mathrm{Pb}^{2+}$ treatments at different concentrations. The highest fresh biomass was observed in the $T_{2}$ treatment $\left(4 \mathrm{mgL}^{-1}\right)$ for both $\mathrm{Cd}^{2+}$ and $\mathrm{Pb}^{2+}$ viz., $206.75 \mathrm{gm} / \mathrm{kg}$ and $193.25 \mathrm{gm} / \mathrm{kg}$, respectively. Fresh plant biomass was found higher than in control treatment i.e. $155.43 \mathrm{gm} / \mathrm{kg}$ which indicated that $\mathrm{CdSO}_{4} \cdot 2 \mathrm{H}_{2} \mathrm{O}$ and solid $\mathrm{PbSO}_{4}$ salts enriched the growing medium and boosted the plant weight below $\mathrm{T}_{2}$ treatment. Kumar et al. (2017a, b) also reported the increased fresh biomass of E. crassipes and Pistia stratiotes plants grown in sugar and paper mill effluents in which, appropriate concentration of $\mathrm{Cd}, \mathrm{Pb}, \mathrm{Al}, \mathrm{Cu}$ and $\mathrm{Fe}$ were present. They also stated that higher the concentration of heavy metals in the effluents acts as toxicants for E. crassipes plants.

Kinetic plant growth rate and total chlorophyll content of $E$. crassipes during phytoremediation experiments were noted at different concentration of $\mathrm{Cd}^{2+}$ and $\mathrm{Pb}^{2+}$ treatments as shown in Figures 3, 4. Increasing kinetic plant growth rate $2.211 \mathrm{gg}^{-1} \mathrm{~d}^{-1}$, $2.261 \mathrm{gg}^{-1} \mathrm{~d}^{-1}$ for $\mathrm{Cd}^{2+} ; 2.101 \mathrm{gg}^{-1} \mathrm{~d}^{-1}, 2.182 \mathrm{gg}^{-1} \mathrm{~d}^{-1}$ for $\mathrm{Pb}^{2+}$; and total chlorophyll content $2.260 \pm 0.10 \mathrm{mg} / \mathrm{gfwt}$ for $\mathrm{Cd}^{2+}$; $2.070 \pm 0.10 \mathrm{mg} / \mathrm{gfwt}$ for $\mathrm{Pb}^{2+}$ were observed viz., highest at $\mathrm{T}_{1}$ and $\mathrm{T}_{2}$ treatment $\left(2 \mathrm{mgL}^{-1}\right.$ and $\left.4 \mathrm{mgL}^{-1}\right)$ due to the conformity of the efficient uptake of these metals and to achieve the maximum growth of plant as earlier reported by (Sooknah and Wilkie, 2014; Kumar et al., 2016) while, the concentration above $4 \mathrm{mgL}^{-1}$ plant growth progressively declined after 30-60 days due to metal induced toxicity in the plant which might be due to the inhibition of chlorophyll processes and biosynthesis (Mukherjee and Kumar, 2005). The reduction in the total chlorophyll content is associated with the higher concentrations of toxic heavy metals treated to the aquatic plant as earlier reported by researchers for water lettuce (De et al., 1985), Cd and $\mathrm{Hg}$ treatment by Hydrilla verticillata and Lemna minor (Chatterjee and Nag, 1991), Pb treated by the Salvina natans (Sen and Bhattacharyya, 1993), $\mathrm{Pb}$ and $\mathrm{Cr}$ treatment by Ipomea aquatica (Alam and Chatterjee, 1994) and $\mathrm{Zn}, \mathrm{Cu}, \mathrm{Cd}$ and $\mathrm{Cr}$ treatment of wastewater using water hyacinth and water lettuce (Kouamé et al., 2016). Therefore, the results indicated that the plant growth attributes viz., total fresh biomass, total chlorophyll content and kinetic plant growth rate of E. crassipes were strongly affected by the different concentrations of $\mathrm{Cd}^{2+}$ and $\mathrm{Pb}^{2+}$. The optimum concentration of $\mathrm{Cd}^{2+}$ and $\mathrm{Pb}^{2+}$ was between 2-4 $\mathrm{mgL}^{-1}$ where, total fresh biomass, total chlorophyll content and kinetic plant growth rate was radially increased.

Translocation factor of $\mathrm{Cd}^{2+}$ and $\mathrm{Pb}^{2+}$ in leaves and roots of $\mathrm{E}$. crassipes

The transport of $\mathrm{Cd}^{2+}$ and $\mathrm{Pb}^{2+}$ from aqueous solution to the roots and again to the leaves of plant of E. crassipes potency is due to necessity and accumulation power, which is controlled by the several physiological and biochemical processes (Kumar et al., 2017a). Figure 5 presented the translocation factor of $\mathrm{Cd}^{2+}$ and $\mathrm{Pb}^{2+}$ in roots to leaves of $E$. crassipes after 60 days of phytoremediation experiments. $\mathrm{T}_{\mathrm{f}}$ was observed highest at 2 $\mathrm{mgL}^{-1}$ concentration for both $\mathrm{Cd}^{2+}$ and $\mathrm{Pb}^{2+}$ treatments i.e. 4.56 and 2.29 correspondingly at 30 day. $\mathrm{Cd}^{2+}$ was found to have high $\mathrm{T}_{\mathrm{f}}$ value than of $\mathrm{Pb}^{2+}$, which means that $E$. crassipes translocate $\mathrm{Cd}^{2+}$ in more quantity in comparison of $\mathrm{Pb}^{2+}$ at $2 \mathrm{ppm}$ concentra- 
tion $\left(\mathrm{T}_{\mathrm{f}}-\mathrm{Cd}^{2+}>\mathrm{T}_{\mathrm{f}}-\mathrm{Pb}^{2+}\right)$. Also, the capability of a plant to translocate metals from the roots to the shoots is estimated by using the translocation factor. Yoon et al. (2006) reported that greater the $T_{f}$ factor values $<1$ higher they are capable to absorb heavy metals from their environment. Thus, the higher $T_{f}$ value (4.56 and 2.29) which was observed at $T_{1}$ treatment of both $\mathrm{Cd}^{2+}$ and $\mathrm{Pb}^{2+}$ at $30^{\text {th }}$ days, indicated that maximum uptake of these metals occurs at $2 \mathrm{mgL}^{-1}$ concentration by $E$. crassipes.

\section{Optimization analysis for $\mathrm{Cd}^{2+}$ and $\mathrm{Pb}^{2+}$ reduction}

One of the main objectives of this study was to find out the optimum concentration of $\mathrm{Cd}^{2+}$ and $\mathrm{Pb}^{2+}$ that could be efficiently reduced by $E$. crassipes from the aqueous solution during the phytoremediation. Table 1 shows that $96 \%$ of $\mathrm{Cd}^{2+}$ and $94 \%$ of $\mathrm{Pb}^{2+}$ was reduced from the aqueous solution at run number 5 . As the concentration of metal was increased the percent reduction (Y\%) was decreased substantially. Determining the prime value for controller variables (factors i.e. independent variables) is one of the main aims of RSM that can take full advantage of a response over a certain area of importance (Khuri and Mukhopadhyay, 2010; Darajeh et al., 2016). The maximum model sum of squares suggested by the Design Expert software was a Two-Factor Interaction (2FI) model for percentage reduction of $\mathrm{Cd}^{2+}$ and $\mathrm{Pb}^{2+}$. The ANOVA for $\mathrm{Cd}^{2+}$ and $\mathrm{Pb}^{2+}$ reduction is presented in Table 2. The 2FI ANOVA models for $\mathrm{Cd}^{+2}$ and $\mathrm{Pb}^{+2}$ reduction had $\mathrm{Xi}$ and $\mathrm{X}_{2}$ as significant factors with Prob $>\mathrm{F}$ of 0.0001 . High percentage removal of $\mathrm{Cd}^{2+}$ and $\mathrm{Pb}^{2+}$ was observed at lower metal concentrations. However, the percent reduction of $\mathrm{Cd}^{2+}$ and $\mathrm{Pb}^{2+}$ was decreased as the concentration of metal treatment was enhanced in the medium.

Higher concentration of $\mathrm{Cd}^{+2}$ and $\mathrm{Pb}^{+2}$ in the aqueous solution was believed to aid as more toxic growing medium of $E$. crassipes. Adequate precision value of 37.48 and 36.83 for $\mathrm{Cd}^{2+}$ and $\mathrm{Pb}^{2+}$ reduction indicated an adequate signal which implies that this model can be used to navigate the design space. The resulting regression models equations for $\mathrm{Cd}^{2+}$ and $\mathrm{Pb}^{2+}$ reduction are given in equation 10 and 11 , respectively.

$$
\begin{aligned}
& Y_{C d}(\%)=32.486-31.19 X_{i}+34.502 X_{j}-31.83 X_{i} X_{j} \\
& Y_{p b}(\%)=29.819-29.555 X_{i}+31.232 X_{j}-31.14 X_{i} X_{j}
\end{aligned}
$$

The equations 10 and 11 can be used to make predictions about the reduction of $\mathrm{Cd}^{2+}$ and $\mathrm{Pb}^{2+}$ for given levels of selected factor. Figure 6 presents the 3D surface plot for $\mathrm{Cd}^{2+}$ and $\mathrm{Pb}^{2+}$ reduction from aqueous solution with respect to two independent variables viz., $\mathrm{X}_{1}$ : concentration and $\mathrm{X}_{2}$ : experimental time. Mojiri et al. (2017) applied RSM-CCD in optimizing the independent factors in biosorption of $\mathrm{Cr}$ (IV) by plant powder, including contact time (24-72 hour) and initial concentration of metal (20-80 $\left.\mathrm{mgL}^{-1}\right)$, and their responses. They reported the prime removal efficacy was 92.3 in react time (48.9 hour) at 50.9 $\mathrm{mgL}^{-1}$ initial concentration of $\mathrm{Cr}(\mathrm{IV})$. The optimization levels given in Table 3 and Figure 7 showed that at $1.22 \mathrm{mgL}^{-1}$ concentration and 54.95 days the model gave maximum percent reduction both of $\mathrm{Cd}^{2+}$ and $\mathrm{Pb}^{2+}$ from the aqueous solution. Therefore, RSM-CCD model was best fitted to predict and optimize the $\mathrm{Cd}^{2+}$ and $\mathrm{Pb}^{2+}$ reduction from the aqueous solution.

\section{Effect of $\mathrm{Cd}^{2+}$ and $\mathrm{Pb}^{2+}$ stress on stomata of E. crassipes}

Microscopic analysis of slides leaves of E. crassipes, stained with Safranine-O showed that $\mathrm{Cd}^{2+}$ and $\mathrm{Pb}^{2+}$ toxicity in growing medium subsequently brought cellular damages. The stomata were shielded by darker (blackish) region which were unable to open and contribute in the process of transpiration. The degree of stomata destruction was recorded significantly increasing with increase in the heavy metal concentration. However, the effect of $\mathrm{Pb}^{2+}$ toxicity was noted higher in comparison to $\mathrm{Cd}^{2+}$ (Figures 8, 9 and Table 4). A slight destruction of stomata was observed in control at 45 and 60 days due to aging of the plant. The stomata opening and closing was maximally inhibited at $\mathrm{T}_{5}$ or $10 \mathrm{mgL}^{-1}$ concentration in both $\mathrm{Cd}^{2+}$ and $\mathrm{Pb}^{2+}$ due to extensive accumulation and toxicity of heavy metals in the leaves cells of the E. crassipes. Stomata are very important structure of the plants they regulate the gaseous exchange, photosynthesis and transpiration rate and ultimately affect the growth of the plants (Cai et al., 2017). The damage in stomata may lead the adverse effects on plant physiology and anatomy which produces stress and consequently affected the remediation efficiency of the $E$. crassipes. Chandra and Kang (2016) also reported the effects of heavy metal stress on photosynthesis, transpiration rate, and chlorophyll content in poplar hybrids. Generally, phytoremediation process is concerned with the metabolism of a plant to uptake and degrades the pollutants. Water content in plants play crucial role in mechanism of photosynthesis and transpiration, and are directly connected with the phytoremediation efficiency of a plant (Sayed, 1997; Sarwar, 2010). The water transport mechanism of plant is affected if the cell membrane permeation is blocked partially or completely by such kind of stress increasing agents, which tend to decrease the phytoremediation rate. Furthermore, the addition of $\mathrm{CdSO}_{4} \cdot 2 \mathrm{H}_{2} \mathrm{O}$ and solid $\mathrm{PbSO}_{4}$ salts increased the $\mathrm{pH}, \mathrm{EC}$ and TDS after hydrolyzing in the water. The bore well water played significant role in providing the nutritional constituents in the medium like minerals instead of desalted distilled water which cannot support the growth of plants. The optimum value of applicable $\mathrm{Cd}^{2+}$ and $\mathrm{Pb}^{2+}$ metal ions was found $\mathrm{T}_{2}$ or $4 \mathrm{mgL}^{-1}$ where the degree of stomata destruction was below $10 \%$ and nearby to the damage threshold with maximum metal remediation from the aqueous solution. Due to the strong affinity of E. crassipes towards bioaccumulation for heavy metals, they can achieve the process of phytoremediation within a tolerable limit, but beyond this limit the heavy metals acts as a cell deteriorating agent and starts to decrease the phytoremediation potential. Consequently, the results showed that the higher contents (more than $\mathrm{T}_{2}$ treatment or $4 \mathrm{mgL}^{-1}$ ) of $\mathrm{Cd}^{2+}$ and $\mathrm{Pb}^{2+}$ in the growing medium were found toxic to the stomata of E. crassipes. 


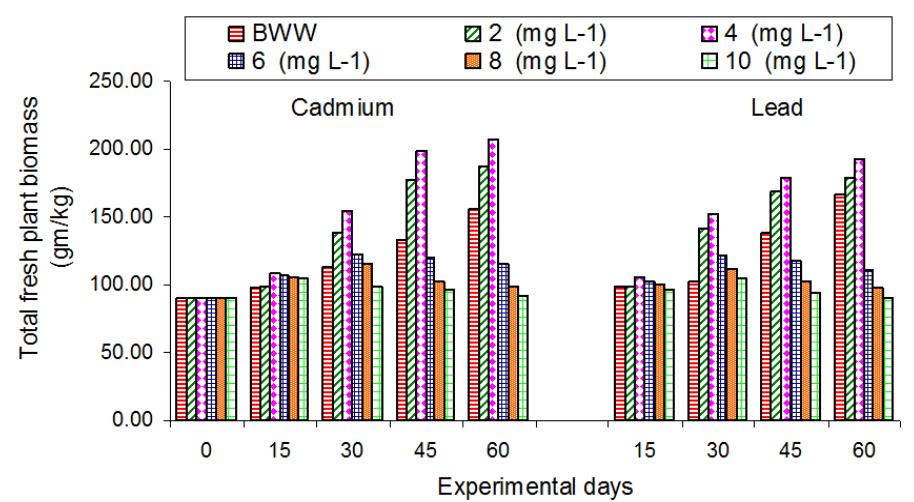

Figure 2. Total fresh biomass of E. crassipes plants in $\mathrm{Cd}^{2+}$ and $\mathrm{Pb}^{2+}$ treatments at different days (BWW: Control).

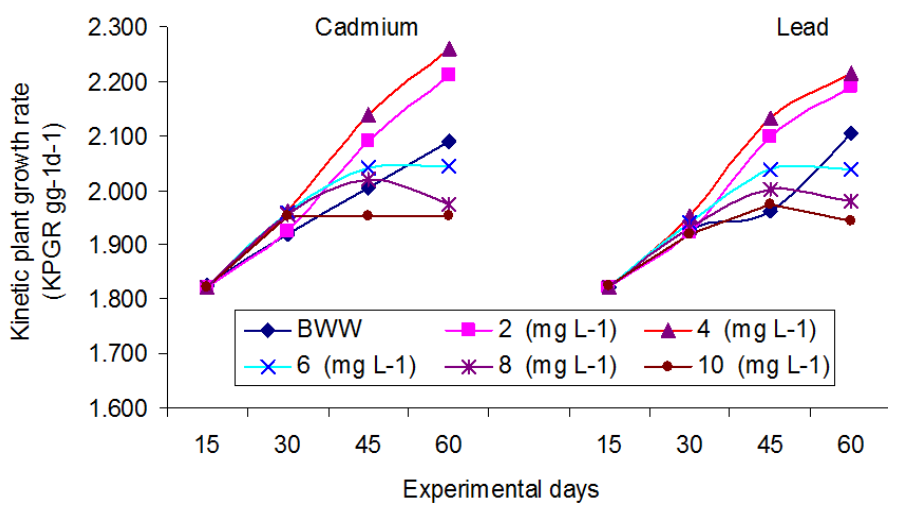

Figure 4. Kinetic plant growth rate of E. crassipes plants in $\mathrm{Cd}^{2+}$ and $\mathrm{Pb}^{2+}$ treatments at different days.

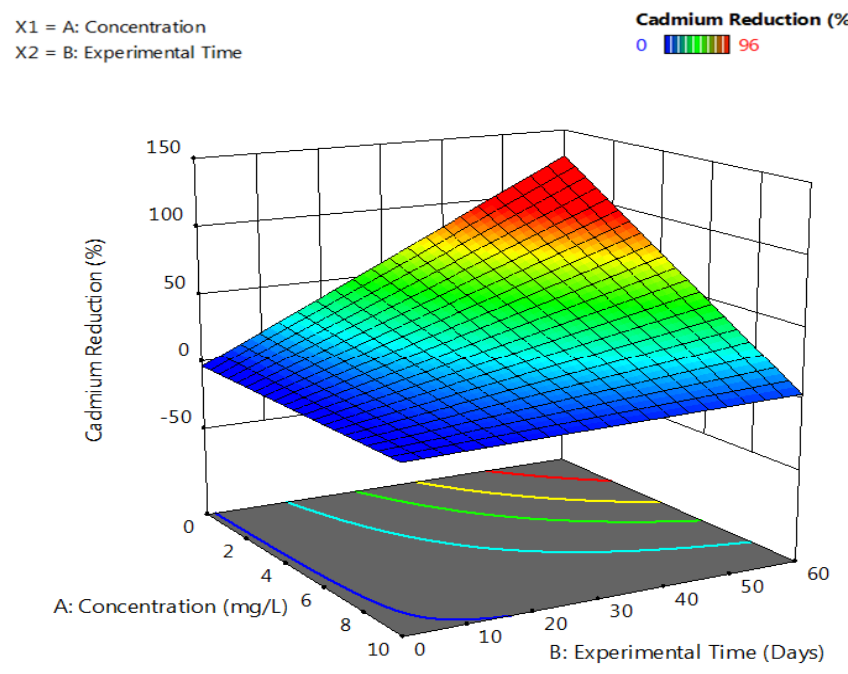

Figure 6. 3D surface Plot for $\mathrm{Cd}^{2+}$ and $\mathrm{Pb}^{2+}$ reduction.
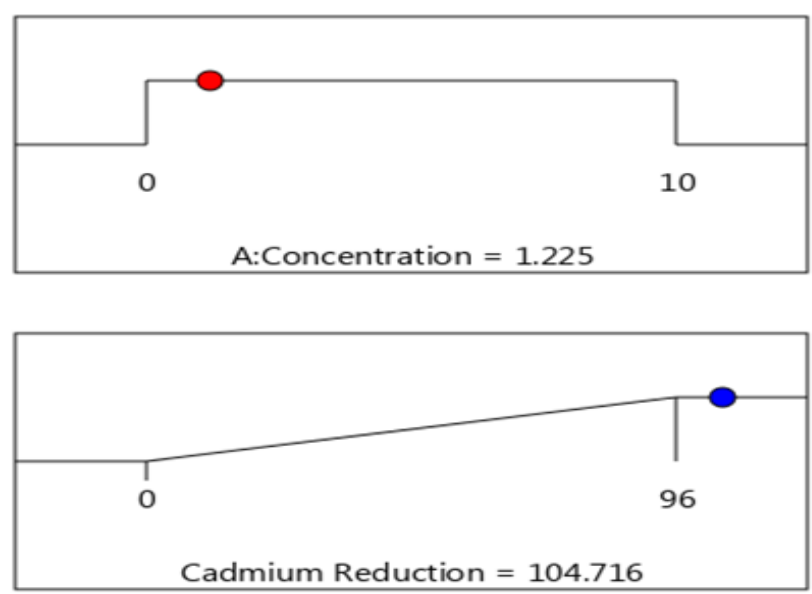

Figure 7. Optimization of $\mathrm{Cd}^{2+}$ and $\mathrm{Pb}^{2+}$ reduction.

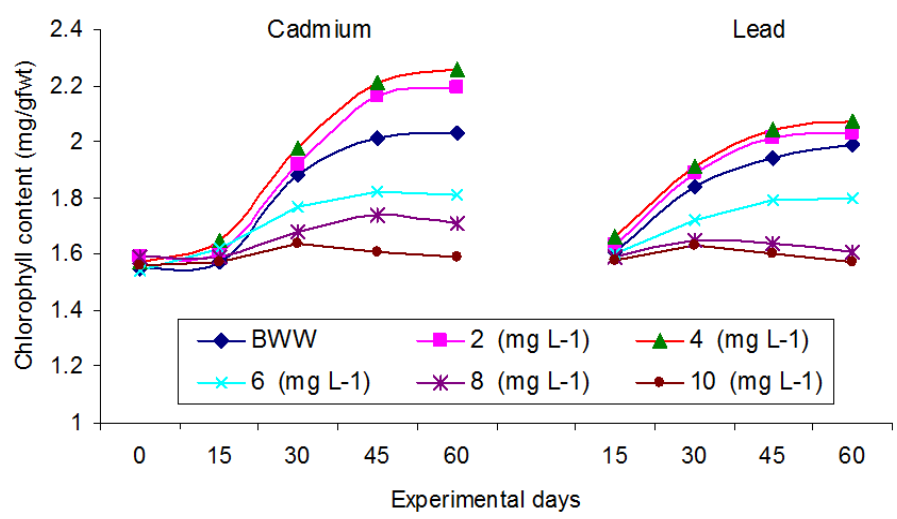

Figure 3. Total chlorophyll content in plants of E. crassipes plants in $\mathrm{Cd}^{2+}$ and $\mathrm{Pb}^{2+}$ treatments at different days.

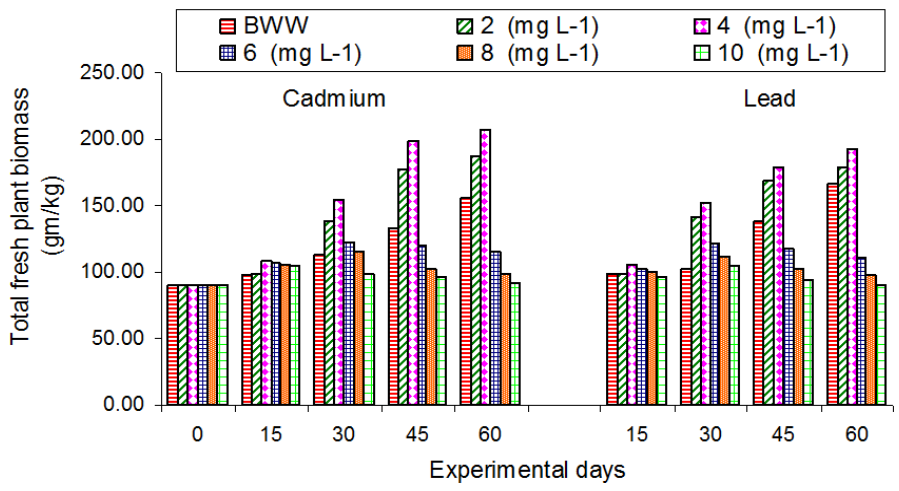

Figure 5. Translocation factor of $\mathrm{E}$. crassipes plants in $\mathrm{Cd}^{+2}$ and $\mathrm{Pb}^{+2}$ treatments at different days.

$$
\begin{array}{ll}
\mathrm{X} 1=\mathrm{A}: \text { Concentration } & \text { Lead Reduction (\%) } \\
\mathrm{X} 2=\mathrm{B}: \text { Experimental Time } & 0 \text { [IIIIIIII) } 94
\end{array}
$$
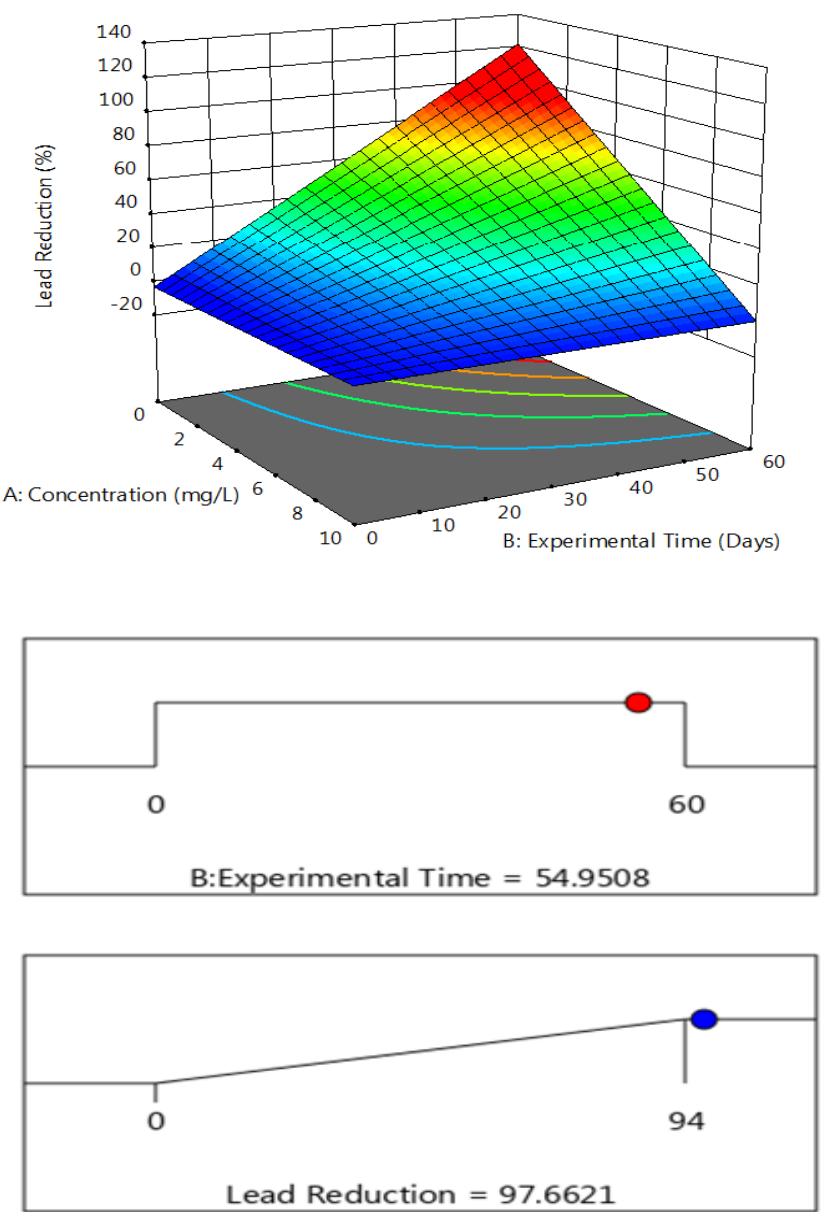

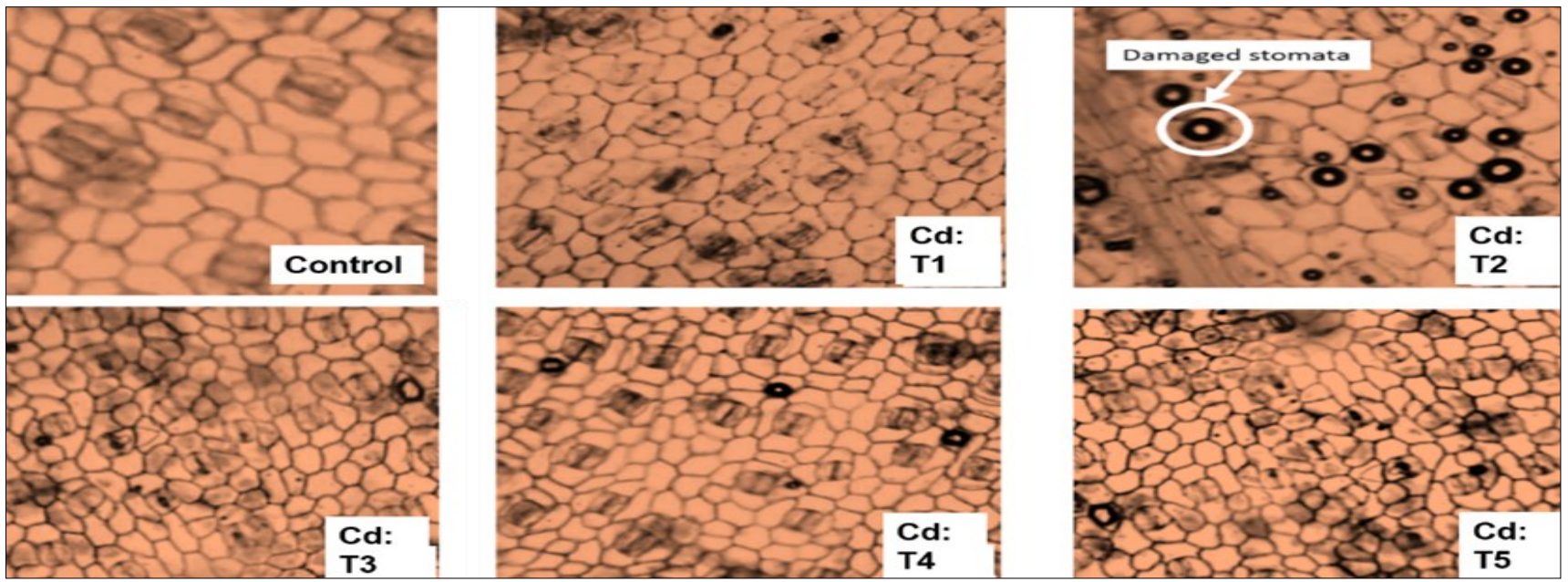

Figure 8. Microscopic view of damaged leaf stomata of E. crassipes at day 60 due to $\mathrm{Cd}^{2+}$ toxicity (resolution: $40 \mathrm{X}$ ).
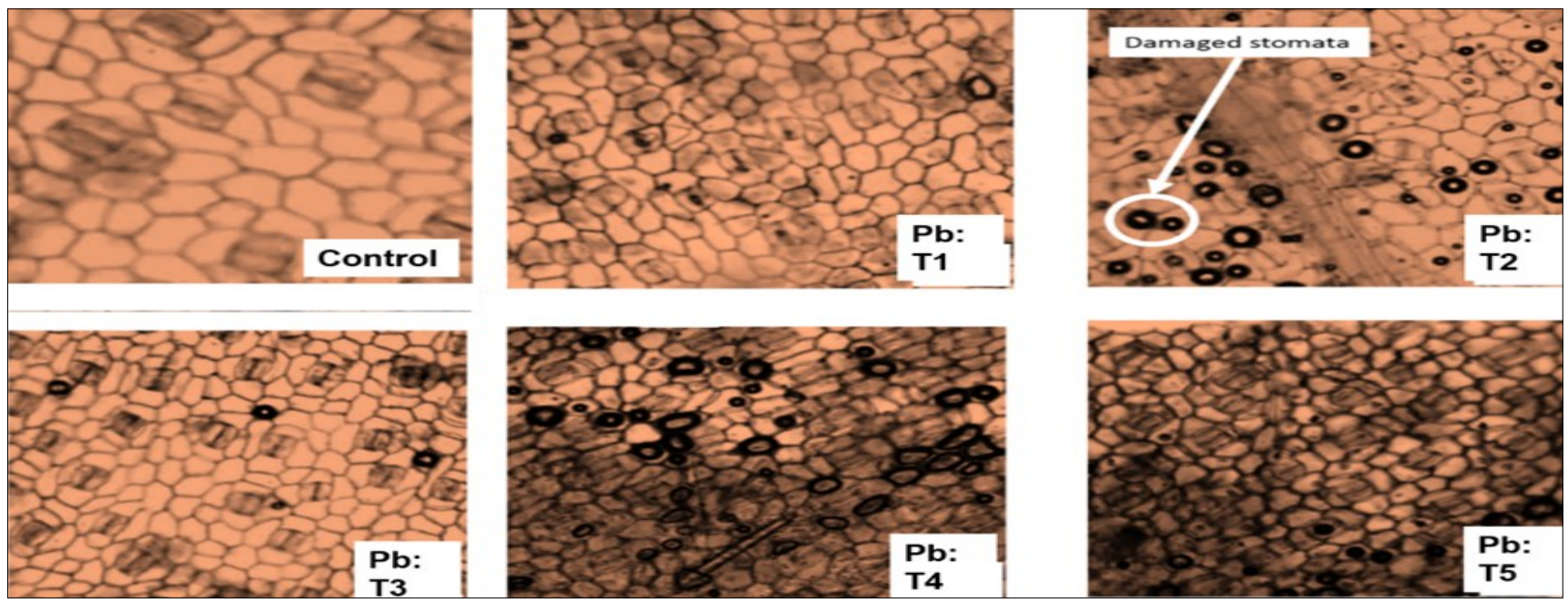

Figure 9. Microscopic view of damaged leaf stomata of E. crassipes at day 60 due to $\mathrm{Pb}^{2+}$ toxicity (resolution: 40X).

Table 1. RSM design for the phytoremediation experiments.

\begin{tabular}{|c|c|c|c|c|}
\hline \multirow{3}{*}{ Run } & Factor $1\left(\mathrm{~A}: \mathrm{X}_{1}\right)$ & Factor $2\left(\mathrm{~B}: \mathrm{X}_{2}\right)$ & Response $1\left(\mathrm{Y}_{1}\right)$ & Response $2\left(\mathrm{Y}_{2}\right)$ \\
\hline & Concentration & Experimental Time & Cadmium Reduction & Lead Reduction \\
\hline & $\mathrm{mgL}^{-1}$ & Days & $\%$ & $\%$ \\
\hline 1 & 2 & 0 & 0 & 0 \\
\hline 2 & 2 & 15 & 19 & 16 \\
\hline 3 & 2 & 30 & 64.5 & 55 \\
\hline 4 & 2 & 45 & 76.5 & 74.5 \\
\hline 5 & 2 & 60 & 96 & 94 \\
\hline 6 & 4 & 0 & 0 & 0 \\
\hline 7 & 4 & 15 & 10.8 & 13.5 \\
\hline 8 & 4 & 30 & 37.8 & 32.5 \\
\hline 9 & 4 & 45 & 76.3 & 70 \\
\hline 10 & 4 & 60 & 91 & 83 \\
\hline 11 & 6 & 0 & 0 & 0 \\
\hline 12 & 6 & 15 & 6 & 11.5 \\
\hline 13 & 6 & 30 & 18.3 & 18 \\
\hline 14 & 6 & 45 & 38.3 & 26.7 \\
\hline 15 & 6 & 60 & 46.8 & 35.2 \\
\hline 16 & 8 & 0 & 0 & 0 \\
\hline 17 & 8 & 15 & 4.9 & 5.5 \\
\hline 18 & 8 & 30 & 8.3 & 8.8 \\
\hline 19 & 8 & 45 & 15 & 15 \\
\hline 20 & 8 & 60 & 23.5 & 19.4 \\
\hline 21 & 10 & 0 & 0 & 0 \\
\hline 22 & 10 & 15 & 1.8 & 0.7 \\
\hline 23 & 10 & 30 & 5.8 & 3.6 \\
\hline 24 & 10 & 45 & 8 & 6.7 \\
\hline 25 & 10 & 60 & 9.6 & 8.1 \\
\hline
\end{tabular}




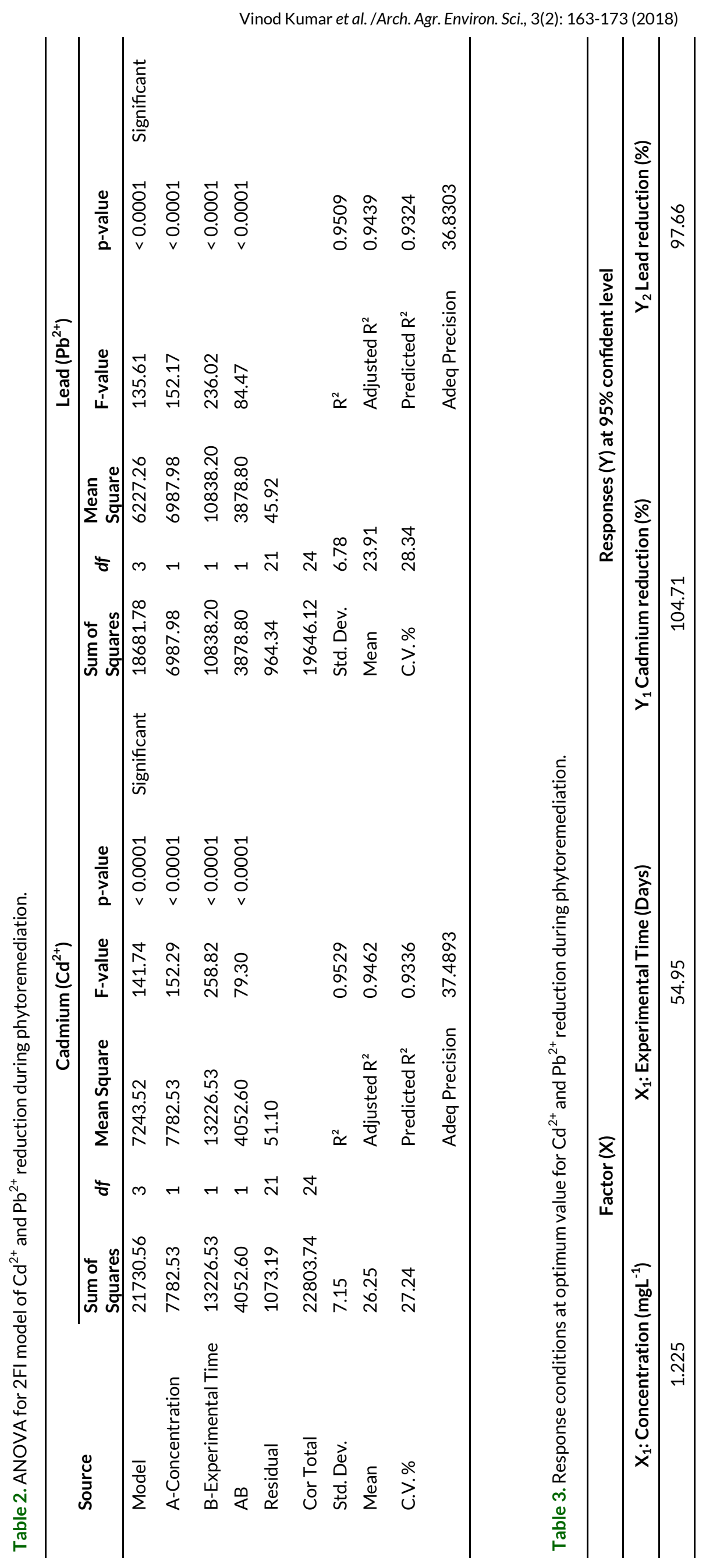


Table 4. Damaged stomata count of E. crassipes in growing medium $\left(\mathrm{Cd}^{2+}\right.$ and $\left.\mathrm{Pb}^{2+}\right)$ during phytoremediation experiment.

\begin{tabular}{|c|c|c|c|c|c|c|c|}
\hline \multirow{2}{*}{ Heavy metals } & \multirow{2}{*}{ Treatments } & \multicolumn{5}{|c|}{ Damaged stomata count ${ }^{*}$} & \multirow{2}{*}{$\% \mathrm{~S}_{\mathrm{D}}$ after 60 days } \\
\hline & & Initial day & 15 days & 30 days & 45 days & 60 days & \\
\hline Control & BWW & 0 & 0 & 0 & 2 & 3 & 6 \\
\hline \multirow{5}{*}{$\mathrm{Cd}^{2+}$} & $2 \mathrm{mgL}^{-1}$ & 0.00 & 0.00 & 3.00 & 4.00 & 6.50 & 13 \\
\hline & $4 \mathrm{mgL}^{-1}$ & 0.00 & 2.00 & 4.00 & 7.95 & 9.26 & 18.52 \\
\hline & $6 \mathrm{mgL}^{-1}$ & 0.00 & 5.64 & 7.90 & 9.72 & 11.19 & 22.38 \\
\hline & $8 \mathrm{mgL}^{-1}$ & 0.00 & 7.61 & 7.34 & 6.80 & 12.12 & 24.24 \\
\hline & $10 \mathrm{mgL}^{-1}$ & 0.00 & 9.82 & 9.42 & 9.20 & 15.04 & 30.08 \\
\hline \multirow{5}{*}{$\mathrm{Pb}^{2+}$} & $2 \mathrm{mgL}^{-1}$ & 0.00 & 0.00 & 4.00 & 5.00 & 7.20 & 14.4 \\
\hline & $4 \mathrm{mgL}^{-1}$ & 0.00 & 3.10 & 4.80 & 8.20 & 10.20 & 20.4 \\
\hline & $6 \mathrm{mgL}^{-1}$ & 0.00 & 5.80 & 8.20 & 10.30 & 12.50 & 25 \\
\hline & $8 \mathrm{mgL}^{-1}$ & 0.00 & 8.20 & 8.70 & 11.40 & 15.60 & 31.2 \\
\hline & $10 \mathrm{mgL}^{-1}$ & 0.00 & 10.20 & 12.50 & 13.60 & 16.70 & 33.4 \\
\hline
\end{tabular}

BWW: Bore well water. Values are mean of stomata count in four microscopic views, \% $\mathrm{S}_{\mathrm{D}}$ : Percent Stomata damage.

Conclusion

The results of this experiment concluded that RSM-CCD model was best fitted to predict and optimize the $\mathrm{Cd}^{2+}$ and $\mathrm{Pb}^{2+}$ reduction from the aqueous solution. The optimum concentration for $\mathrm{Cd}^{2+}$ and $\mathrm{Pb}^{2+}$ phytoremediation using E. crassipes was found $1.22 \mathrm{mgL}^{-1}$ in 54 days experiment in which maximum amount of $\mathrm{Cd}^{2+}$ and $\mathrm{Pb}^{2+}$ was reduced from the aqueous solution. Furthermore, the translocation factor kinetic plant growth rate, fresh plant biomass and total chlorophyll contents were also found positively correlated with the $\mathrm{Cd}^{2+}$ and $\mathrm{Pb}^{2+}$ concentration up to $4 \mathrm{mgL}^{-1}$ and after it negatively. Moreover, the concentrations $<4$ $\mathrm{mgL}^{-1}$ of $\mathrm{Cd}^{2+}$ and $\mathrm{Pb}^{2+}$ produced structural damage to the stomata in the leaves of E. crassipes. The number of damaged stomata of E. crassipes was also increased with the increase in the contents of $\mathrm{Cd}^{2+}$ and $\mathrm{Pb}^{2+}$ in the growing medium. The higher contents $\left(T_{5}\right.$ or $\left.10 \mathrm{mgL}^{-1}\right)$ of $\mathrm{Cd}^{2+}$ and $\mathrm{Pb}^{2+}$ in the growing medium were found very toxic to the stomata of E. crassipes. Among both the metals, $\mathrm{Pb}^{2+}$ produced more damage to stomata of E. crassipes in comparison of $\mathrm{Cd}^{2+}$. This study suggested that the anatomical and ultra-structural characteristics may be used as a part of the studies on the modifications caused by the potentially toxic metals and other plant pollutants and using $E$. crassipes for phytoremediation purposes by enabling to control heavy metals levels within its tolerable limits using the proposed RSM-CCD. Further research is required to study the effects of heavy metals toxicity on anatomical, physiological and biochemical processes like water balance, gaseous exchange, transpiration rate and photosynthetic rate of $E$. crassipes which likely affects the phytoremediation potential of E. crassipes.

\section{ACKNOWLEDGEMENTS}

The Universities Grants Commission, New Delhi, India is acknowledged to provide Meritorious Rajiv Gandhi National Fellowship (RGNF) F1-17.1/ 2015-16/ RGNF-2015-17-SC-UTT5597/ (SA-III/ Website) to Jogendra Singh.

Conflict of interest: The authors declare that they have no conflict of interest.
Open Access: This is open access article distributed under the terms of the Creative Commons Attribution License, which permits unrestricted use, distribution, and reproduction in any medium, provided the original author(s) and the source are credited.

\section{REFERENCES}

Acharya, B.R. and Assmann, S.M. (2009). Hormone interactions in stomatal function. Plant Molecular Biology, 69: 451-462, https://doi.org/10.1007/s11103-008-9427-0

Alam, B. and Chatterjee, A.K. (1994). Ipomea aquatica as a possible biomonitor of aquatic Lead and Chromium Pollution. In: M. Roy (Ed.) Recent Researches in Ecology, Environment and Pollution, Vol. 9, (New Delhi: Today and Tomorrows Printers and Publishers), pp. 217-277.

Anderson, M.J. and Whitcomb, P.J. (2005). RSM simplified: optimizing processes using response surface methods for design of experiments. Productivity press.

AOAC (2005). Official methods of analysis of the association of official analytical chemists. $13^{\text {th }}$ ed. Rockville (MD): AOAC International, p. 545-567.

APHA (2012). Standard methods for the examination of water and waste water. Washington (DC): American Public Health and Association, 2012; p. 2462.

Aron, D. (1949). Copper enzymes isolated chloroplasts, polyphenol oxidase in Beta vulgaris. Plant Physiology, 24:1-15.

Baruah, K.K., Gogoi, B., Borah, L., Gogoi, M. and Boruah, R. (2012). Plant morphophysiological and anatomical factors associated with nitrous oxide flux from wheat (Triticum aestivum). Journal of Plant Research, 125(4): 507-516.

Batool, R., Hameed, M., Ashraf, M., Ahmad, M.S. and Fatima, S. (2015). Physio-Anatomical Responses of Plants to Heavy Metals. In: Öztürk M, Ashraf M, Aksoy A, Ahmad M (eds) Phytoremediation for Green Energy. Springer, Dordrecht, https://doi.org/10.1007/978-94-007-7887-0_5

Cai, Q., Ji, C., Yan, Z., Jiang, X. and Fang, J, (2017). Anatomical responses of leaf and stem of Arabidopsis thaliana to nitrogen and phosphorus addition. Journal of Plant Research, 130(6): 1035-1045. 
Chandra, C. and Kang, H. (2016). Mixed heavy metal stress on photosynthesis, transpiration rate, and chlorophyll content in poplar hybrids. Forest Science and Technolology, 12:2, 5561, https://doi.org/10.1080/21580103.2015.1044024

Chatterjee, A.K. and Nag, U. (1991). Biomonitoring of aquatic metal pollution, International Journal of Hygiene and Environmental Health, 1(1): 166.

Chaturvedi, R.K. and Sankar, K. (2006). In: Laboratory manual for the physico-chemical analysis of soil, water and plant. Wildlife Institute of India, Dehradun. pp 97.

Darajeh, N., Idris, A., Masoumi, H.R.F., Nourani, A., Truong, P. and Sairi, N.A. (2016). Modeling BOD and COD removal from Palm Oil Mill Secondary Effluent in floating wetland by Chrysopogon zizanioides (L.) using response surface methodology. Journal of Environmental Management, 181:343-352.

De, A.K., Sen, A.K., Modak, D.P. and Jana, S. (1985). Studies on toxic effects of $\mathrm{Hg}$ (II) on Pistia stratiotes L. Water Air Soil Pollution, 24(3): 351-360.

Deka, J. and Sarma, H.P. (2012). Heavy metal contamination in soil in an industrial zone and its relation with some soil properties. Archives of Applied Science Research, 4(2): 831836

Di Gregorio, S., Giorgetti, L., Castiglione, M.R., Mariotti, L. and Lorenzi, R. (2015). Phytoremediation for improving the quality of effluents from a conventional tannery wastewater treatment plant. International Journal of Environmental Science and Technology, 12(4): 1387-1400.

Freitas, R.B.D., Alves, J.D., Magalhães, M.M., Goulart, P.D.F.P., Nascimento, M.N.D. and Fries, D.D. (2007). Coffee tree fertilization with potassium nitrate via leaf and soil, in autumn-winter and spring-summer: effects on nitrate reductase activity, on plant growth and production. Ciência e Agrotecnologia, 31(4): 945-952.

Hall, J.L. (2002). Cellular mechanisms for heavy metal detoxification and tolerance. Journal of Experimental Botany, 53: 1-11.

Hessini, K., Ghandour, M., Albouchi, A., Soltani, A., Werner, K.H. and Abdelly, C. (2008) Biomass production, photosynthesis, and leaf water relations of Spartina alterniflora under moderate water stress. Journal of Plant Research, 121(3): 311-318.

Hultine, K.R. and Marshall, J.D. (2001). A comparison of three methods for determining the stomatal density of pine needles. Journal of Experimental Botany, 52(355): 369-373.

Hunt, R. (1978). Plant growth analysis. Studies in biology. London: Edward Arnold.1978; P. 67

Hurst (1997) Water Microbiology in Public Health. Manual of Environmental Microbiology. ASM Press, Washington, DC.

lida, S., Ikeda, M., Amano, M., Sakayama, H., Kadono, Y., Kosuge, K. (2016). Loss of heterophylly in aquatic plants: not ABAmediated stress but exogenous $A B A$ treatment induces stomatal leaves in Potamogeton perfoliatus. Journal of Plant Research, 129(5): 853-862.

Khuri, A.I. and Mukhopadhyay, S. (2010). Response surface methodology. Wiley Interdisciplinary. Reviews Computational Statistics, 2 (2): $128 \mathrm{e} 149$.

Kumar, V. and Chopra, A.K. (2016). Reduction of pollution load of paper mill effluent by phytoremediation technique using water caltrop (Trapa natans L.). Cogent Environmental Science, 2: 1153216 https://doi.org/ 10.1080/ 23311843. 2016.1153216

Kumar, V. and Chopra, A.K. (2017). Phytoremediation potential of water caltrop (Trapa natans L.) using municipal wastewater of the activated sludge process-based municipal wastewater treatment plant, Environmental Technology, 39(1): 12-23, https:// doi.org/ 10. 1080/09593330. 2017. 1293165

Kumar, V., Chopra, A.K., Singh, J., Thakur, R.K., Srivastava, S. and Chauhan, R.K. (2017b). Comparative assessment of phytoremediation feasibility of water caltrop (Trapa natans L.) and water hyacinth (Eichhornia crassipes Solms.) using pulp and paper mill effluent. Archives of Agriculture and Environmental Science, 1(1): 13-21.

Kumar, V., Singh, J. and Chopra, A.K. (2017a). Assessment of phytokinetic removal of pollutants of paper mill effluent using water hyacinth (Eichhornia crassipes [Mart.] Solms), Environmental Technology, https://doi.org/ 10. 1080/ 09593330.2017.1365944

Kumar, V., Singh, J. and Chopra, A.K. (2018). Assessment of plant growth attributes, bioaccumulation, enrichment and translocation of heavy metals in water lettuce (Pistia stratiotes L.) grown in sugar mill effluent, International Journal of Phytoremediation, 20:5, 507-521, https://doi.org/ 10.1080/15226514.2017.1393391

Kumar, V., Singh, J., Pathak, V.V., Ahmad, S. and Kothari, R. (2017c). Experimental and kinetics study for phytoremediation of sugar mill effluent using water lettuce (Pistia stratiotes L.) and its end use for biogas production. 3 Biotech 7: 330. https://doi.org/10.1007/s13205-017-0963-7

Letachowicz, B., Krawczyk, J. and Klink, A. (2006). Accumulation of heavy metals in organs of Typha latifolia. Polish Journal of Environmental Studies, 15(2a): 407-409.

Liao, S.W. and Chang, W.L. (2004). Heavy metal phytoremediation by water hyacinth at constructed wetlands in Taiwan. Journal of Aquatic Plant Management, 42: 60-68.

Mahmood, T., Malik, S.A. and Hussain, S.T. (2010). Biosorption and recovery of heavy metals from aqueous solutions by Eichhornia crassipes (water hyacinth) ash. BioResources, 5(2): 1244-1256.

Mellem, J., Baijnath, H. and Odhav, B. (2009). Translocation and accumulation of $\mathrm{Cr}, \mathrm{Hg}, \mathrm{As}, \mathrm{Pb}, \mathrm{Cu}$ and $\mathrm{Ni}$ by Amaranthus dubius (Amaranthaceae) from contaminated sites. Journal of Environmental Science and Health Part A, 44:568-575.

Mellem, J., Baijnath, H. and Odhav, B. (2012). Bioaccumulation of $\mathrm{Cr}, \mathrm{Hg}, \mathrm{As}, \mathrm{Pb}, \mathrm{Cu}$ and $\mathrm{Ni}$ with the ability for hyperaccumulation by Amaranthus dubius. African Journal of Agricultural Research, 7:591-596.

Mojiri, A., Tajuddin, R.M., Ahmad, Z., Ziyang, L., Aziz, H.A., and Amin, N.M. (2017). Chromium (VI) and cadmium removal 
from aqueous solutions using the BAZLSC/cockle shell constructed wetland system: optimization with RSM. International Journal of Environmental Science and Technology, 1-8, https://doi.org/10.1007/s13762-017-1561-2

Mondal, N.K., Chattoraj, Sadhukhan, S.B. and Das, B. (2013) Evaluation of carbaryl sorption in alluvial soil, Songklanakarin Journal of Science \& Technology, 35 (6):727-738.

Mourabet, M., El Rhilassi, A., El Boujaady, H., Bennani-Ziatni, M., El Hamri, R. and Taitai, A. (2015). Removal of fluoride from aqueous solution by adsorption on hydroxyapatite (HAp) using response surface methodology. Journal of Saudi Chemical Society, 19(6), 603-615.

Mukherjee, S. and Kumar, S. (2005). Arsenic uptake potential of water lettuce (Pistia Stratiotes L.). International Journal of Environmental Studies, 62(2): 249-258.

Perfus-Barbeoch. L., Leonhardt. N., Vavasseur, A. and Forestier, C. (2002) Heavy metal toxicity: cadmium permeates through calcium channels and disturbs the plant water status. The Plant Journal, 32: 539-548.

Salehi, K., Bahmani, A., Shahmoradi, B., Pordel, M.A., Kohzadi, S., Gong, Y. and Lee, S.M. (2017). Response surface methodology (RSM) optimization approach for degradation of Direct Blue 71 dye using $\mathrm{CuO}-\mathrm{ZnO}$ nanocomposite. International Journal of Environmental Science and Technology, 14(10): 2067-2076.

Sarwar, N., Malhi, S.S., Zia, M.H., Naeem, A., Bibi, S. and Farid, G. (2010). Role of mineral nutrition in minimizing cadmium accumulation by plants. Journal of the Science of Food and Agriculture, 90(6): 925-937.

Sayed, S.A. (1997). Effect of cadmium and kinetin on transpiration rate, stomatal opening and leaf relative water content in safflower plants. Journal of Islamic Academy of Sciences, 10 (3): 73-80.

Sen, A. K. and Bhattacharyya, M.A.N.I.S.H.A. (1993). Studies on uptake and toxic effects of lead on Salvinia natans. Indian
Journal of Environmental Health, 35(4): 308-320.

Singh, D., Tiwari, A. and Gupta, R. (2012). Phytoremediation of lead from wastewater using aquatic plants. Journal of Agricultural Technology, 8(1): 1-11.

Sooknah, R.D. and Wilkie, A.C. (2004). Nutrient removal by floating aquatic macrophytes cultured in anaerobically digested flushed dairy manure wastewater. Ecological Engineering, 22(1): 27-42.

Victor, K.K., Séka, Y., Norbert, K.K., Sanogo, T.A. and Celestin, A.B. (2016). Phytoremediation of wastewater toxicity using water hyacinth (Eichhornia crassipes) and water lettuce (Pistia stratiotes). International Journal of Phytoremediation, 18(10): 949-955, https://doi.org/ 10.1080/15226514.2016.1183567

Wantala, K., Khongkasem, E., Khlongkarnpanich, N., Sthiannopkao, S. and Kim, K.W. (2012). Optimization of As (V) adsorption on Fe-RH-MCM-41-immobilized GAC using Box-Behnken Design: Effects of $\mathrm{pH}$, loadings, and initial concentrations. Applied Geochemistry, 27(5): 1027-1034.

Wei, J., Liu, X., Zhang, X., Chen, X., Liu, S. and Chen, L. (2014). Rhizosphere effect of Scirpus triqueter on soil microbial structure during phytoremediation of diesel-contaminated wetland. Environmental Technology, 35(4): 514-520.

Yoon, J., Cao, X., Zhou, Q. and Ma, L.Q. (2006). Accumulation of $\mathrm{Pb}, \mathrm{Cu}$, and $\mathrm{Zn}$ in native plants growing on a contaminated Florida site. Science of the Total Environment, 368(2-3): 456464.

Zaranyika, M.F. and Nyati, W. (2017). Uptake of heavy metals by Typha capensis from wetland sites polluted by effluent from mineral processing plants: implications of metal-metal interactions. 3 Biotech, 7(5): 286.

Zheng, Y. and Wang, A. (2010). Removal of heavy metals using polyvinyl alcohol semi-IPN poly (acrylic acid)/tourmaline composite optimized with response surface methodology. Chemical Engineering Journal, 162(1): 186-193. 